\title{
ESTIMATION OF REVISED CAPACITY IN GOBIND SAGAR RESERVOIR USING GOOGLE EARTH ENGINE AND GIS
}

\author{
Sachchidanand Singh ${ }^{1,}{ }^{*}$, Manish Kumar Dhasmana ${ }^{1}$, Vaibhav Shrivastava $^{1}$, Vishal Sharma ${ }^{1}$, Neha Pokhriyal $^{1}$, \\ Praveen K. Thakur ${ }^{2}$, S. P Aggarwal ${ }^{2}$, Bhaskar R. Nikam², Vaibhav Garg², Arpit Chouksey², Pankaj R. Dhote ${ }^{1}$ \\ ${ }^{1}$ Water Resource Department, Indian Institute of Remote Sensing, Dehradun, India - \\ (sachin.iirs,manishdhasmana49,iirs.vaibhav,vishal.iirs, nehanpokhriyal,Pankaj.dhote99)@gmail.com \\ ${ }^{2}$ Water Resource Department, Indian Institute of Remote Sensing, Dehradun, India - (praveen, spa, bhaskarnikam, vaibhav, \\ arpit)@iirs.gov.in
}

\section{Commission V, SS: Emerging Trends in Geoinformatics}

KEY WORDS: NDWI, Capacity curve, Sedimentation, Cumulative Capacity, Water-Spread Area, Google Earth Engine, GIS, Satellite Data

\begin{abstract}
:
Capacity studies of reservoirs are important to evaluate sedimentation and optimize reservoir operation schedule based on realistic assessment of available storage. Capacity study at regular interval provide information about rate and pattern of sedimentation between various levels, loss of capacity due to sedimentation, remaining time span of reservoir, etc. In the present study, evaluation of revised capacity of Gobind Sagar reservoir in Bilaspur district, Himachal Pradesh, India has been done using Google Earth Engine. Landsat 8 (OLI) data for September 2015 and for the period September 2017 to May 2018 covering full extent of Gobind Sagar reservoir is taken to compute the water spread area of this reservoir at different dates. Subsequently, the reservoir water level and volume of water stored on the corresponding dates is acquired from India-WRIS. By using trapezoidal formula capacity between two elevations is determined using water spread area obtained from Google Earth Engine analysis and elevation data obtained from India-WRIS. The comparison of water spread areas of different water levels, as obtained from remotely sensed data from September 2017 to May, 2018 with those from survey carried out during 1996/97, indicates a reduction in the capacity by $10.71 \%$ and sedimentation rate was estimated to be $14.24 \mathrm{Mm}^{3} /$ year.
\end{abstract}

\section{INTRODUCTION}

Although, lakes and reservoirs occupy a small part of the Earth's land surface (Verpoorter, Kutser, Seekell, \& Tranvik, 2014), they are vital elements of the hydrological cycles. The valuable life of reservoir can be found by assessing sedimentation rate which causes reduction in the reservoir storage capacity. This loss of capacity in reservoir affects the planned long-term utilization of project for, urban water supply, flood mitigation and irrigation. The total time span of a reservoir starts reducing soon after its commissioning due to continuous deposition of waterborne sediments washed/eroded from various parts of catchment. The suspended sediments start settling down in the reservoir bed and decreases the storage capacity of the reservoir (Foteh et al., 2018; Morris, 1995; Shalash, 1982; Shukla, Jain, Kansal, \& Chandniha, 2017). A wide estimate of soil erosion in India indicates that ever year about 5334 million tons of soil is being lost, which implies, rate of soil erosion to be 16.35 tones/hectare/year (Narayana \& Babu, 1983), whereas the allowed soil loss tolerance value is 4.5 - 11.2 tones/hectare/year. As per Narmada Valley Development Authority (1992) survey done in respect of 43 reservoirs in India indicated that the rate of sedimentation varies between 0.3 to $27.85 \mathrm{ha}-\mathrm{m} / 100 \mathrm{~km} / \mathrm{year}$. On the basis of screening analysis of available data, (Morris, 1995) reported that till this date some reservoirs in India have lost about 50\% of their capacity. Expectedly, 27 out of 116 reservoirs would have lost half of their original capacity by 2020 and by the year $2050,20 \%$ of existing reservoirs would have lost $50 \%$ of their capacity (Durbude \& Purandara, 2005)
Present conventional method of sedimentation quantification in reservoir, like hydrographic survey and inflow/outflow method are cumbersome, expensive and time consuming and need experienced manpower and refined instruments. By using empirical and numerical techniques prediction of sediment deposition is done which requires large amounts of data and the results are still less accurate (Goel, Jain, \& Agarwal, 2002). By using remote sensing it becomes very convenient to estimate sedimentation in reservoir (Ninija Merina, R. Sashi Kumar, M. C., Rizvana, N., Adlin, 2016). Remote sensing techniques are superior to the other conventional techniques (such as hydrographic surveys and inflow-outflow records), as it provides data availability over a long time span with a wide spectral range (Goel et al., 2002). Satellite data is being used since long time to calculate the water-spread area for different elevations of a reservoir, which as a result is used to estimate the capacity of the reservoir.

The GEE is a system designed to enable petabyte-scale, scientific analysis and visualization of geospatial datasets. Earth Engine provides a consolidated environment including a massive data catalog co-located with thousands of computers for analysis( Xiong et al., 2017). By using Google Earth Engine and geographic information system the temporal change in water spread area is analysed to evaluate the pattern of sediment deposition in a reservoir. Numerous studies have been done in the past related to reservoir sedimentation, soil erosion modelling etc. (Durbude \& Purandara, 2005; Fan \& Morris, 1992; Foteh et al., 2018; Garg \& Jothiprakash, 2008; GOEL et al., 2002; Jain, 2002.; Narayana \& Babu, 1983; Prasad et al.,

\footnotetext{
${ }^{*}$ Corresponding Author
} 
2018; Shukla et al., 2017) however, still no work has been done for the evaluation of reservoir capacity using Google Earth Engine as a tool. In the present study, evaluation of revised capacity of Gobind Sagar reservoir in Bilaspur district of Himachal Pradesh, India has been carried out by using Google Earth Engine. Landsat 8 OLI sensor data taken of September 2015 and from September 2017 to May 2018 for Gobind Sagar Reservoir, Himachal Pradesh, India to compute the water spread area.

\section{STUDY AREA}

The Sutlej River originates from the lakes of Rakastal and Mansarover in the Tibetan Plateau, which is the southern slopes of Mount Kailash (elevation approx. 4,570 m above MSL) and is one of the main tributaries of Indus River. It covers about 322 $\mathrm{km}$ in the Tibetan province of Nari-Khorsam, then near Khab enters into the India. Hereafter, the river flows through Himachal Pradesh and Punjab states of India. It changes its direction from north-westerly to south-west direction and flows about $322 \mathrm{~km}$ up to Bhakra gorge.

Gobind Sagar reservoir is a high straight gravity dam of $225 \mathrm{~m}$ height and is located in Bilaspur District, Himanchal Pradesh, in between $31^{\circ} 24^{\prime} 39^{\prime \prime}$ North Latitude and $76^{\circ} 26^{\prime} 0^{\prime \prime}$ East Longitude which is an artificial lake formed by the Bhakra Dam across river Sutlej (Fig. 1). The construction of dam started in 1955 and completed in 1962. The entire catchment area of the reservoir is $56980 \mathrm{~km}^{2}$ and spread area is $168.35 \mathrm{~km}^{2}$. Its total length is $90 \mathrm{~km}$. the estimated annual runoff of this reservoir is 16775 million $\mathrm{m}^{3}$. The mean and maximum depths of the reservoir are $55 \mathrm{~m}$ and $163.07 \mathrm{~m}$ respectively, which makes it one of the deepest artificial lake in the world. The main purposes of its construction are hydropower generation, flood control and irrigation. It is one of the highest gravity dam in the world.

\begin{tabular}{|c|c|}
\hline Features Details & $\begin{array}{c}\text { Gobind Sagar } \\
\text { Reservoir }\end{array}$ \\
\hline Construction Year & 1963 \\
\hline Installed capacity & $1325 \mathrm{MW}$ \\
\hline Height above river bed & $167.64 \mathrm{~m}(550 \mathrm{ft})$ \\
\hline $\begin{array}{c}\text { Elev. at top of dam } \\
\text { (from msl) }\end{array}$ & $518.16 \mathrm{~m}$ \\
\hline Normal reservoir level & $512.06 \mathrm{~m}$ \\
\hline Catchment area & $56980 \mathrm{sq} . \mathrm{km}$ \\
\hline Reservoir length & $96.56 \mathrm{~km}$ \\
\hline Live storage capacity & $6911 \mathrm{M.cum}$ \\
\hline Gross storage capacity & $9340 \mathrm{M} . \mathrm{cum}$ \\
\hline Surface area & $168.35 \mathrm{sq} . \mathrm{km}$. \\
\hline Type of dam & $\begin{array}{c}\text { Earth-fill Concrete } \\
\text { gravity dam }\end{array}$ \\
\hline
\end{tabular}

Table 1. Gobind Sagar Reservoir features detail

The variability of climate in the study area is inconsistent and it differentiates between dry (October-May) and wet (June to September) seasons. According to Indian Meteorological Department (IMD), the Bilaspur district receives average annual rainfall of about $1258 \mathrm{~mm}$. The major land use types comprise of degraded forest, forest, grassland, cropland, and orchard.
Forests are sullied in low mountain areas because of easy approachability of the settlement areas located in lowlands (Shrestha et al., 2012). (Singh \& Kumar, 1997) have calculated the precipitation in various Himalayan river basins and established that during monsoon season contribution to the annual rainfall is maximum (42-60\%), whereas post-monsoon season contributes the minimum (5-10\%).



Fig. 1. Study Area

\section{DATA AND TOOLS USED}

\subsection{Google Earth Engine (GEE)}

GEE combines a multi-petabyte catalogue of satellite imagery and geospatial datasets with planetary-scale analysis capabilities and makes it available for scientists, researchers, and developers to detect changes, map trends, and quantify differences on the Earth's surface (Google Earth Engine Team). It is thus a tool for analysing geospatial information with an application programming interface (API) which is available in Python and JavaScript. Here, the methods are built on using JavaScript (Zeltner, 2016). The GEE data catalogue shows a variety of different datasets. The user has access to images from different satellite images providers such as MODIS, LANDSAT, SENTINEL or digital elevation data from the Shuttle Radar Topography Mission (SRTM). GEE data catalogue includes satellite data in raw format, orthorectified imagery, top-ofatmosphere-and surface reflectance data (Gorelick et al., 2017)

\subsection{Satellite data:}

GEE was used to analyse and detect the water spread area using the Landsat 8 TOA Reflectance data from September 2017 to May 2018 with a condition of cloud cover of less than $10 \%$. Also, for the maximum reservoir level $(511.32 \mathrm{~m})$, Landsat 8 TAO reflectance data for September 2015 was also analysed.

\subsection{Reservoir water level data:}

Elevation data, corresponding to the optical image acquired from Google Earth Engine, for Gobind Sagar was obtained from India-WARIS portal for the period of September 2017 to 2018. Also for the calculation of reservoir capacity, the original reservoir data for the period of 1996/97 was obtained from Bhakra Beas Management Board (BBMB)(Sanjay k. Jain , Singh Pratap, 2002). During the study year 2017/18, the maximum reservoir level $(508.64 \mathrm{~m})$ was observed on September 20, 2017, which gradually reduced to minimum level 
of 467.38 on May 2, 2018. However, to cover the full extent of reservoir capacity i.e. from minimum reservoir level $(467.38 \mathrm{~m})$ to maximum reservoir level $(511.32 \mathrm{~m})$, one image for September 2015 was analysed. The difference between spread of water between present year and earlier years is directly related to extent of silting at these levels.

\subsection{Data Collection:}

A separate algorithm was applied to import cloud free Landsat 8 TOA Reflectance data in GEE, which was then exported to google drive. For the study area, almost seven cloud free images were obtained as shown in Table 2. The reservoir water level of corresponding dates is obtained from India-WRIS.

\begin{tabular}{|c|c|}
\hline $\begin{array}{c}\text { Date of Image } \\
\text { acquisition }\end{array}$ & Elevation $(\mathbf{m})$ \\
\hline 2-May-18 & 467.38 \\
\hline 27-Feb-18 & 486.39 \\
\hline 9-Dec-17 & 503.31 \\
\hline 7-Nov-17 & 506.51 \\
\hline 6-Oct-17 & 507.8 \\
\hline 20-Sep-17 & 508.64 \\
\hline
\end{tabular}

Table 2. Date of acquisition of Landsat 8 image and corresponding reservoir level

\section{METHODOLOGY}

\subsection{Estimation of water spread area:}

The reduction in capacity of reservoir can be depicted by decrease in water spread area of respective water levels. For the present study, Normalized Difference Water Index (NDWI) was generated and used for extracting water pixels. The NDWI is a method that delineates open water features and enhances their presence in remotely sensed digital imagery and simultaneously eliminates soil and terrestrial vegetation features.(McFeeters, 1996)

$$
\mathrm{NDWI}=(\mathrm{G}-\mathrm{NIR}) /(\mathrm{G}+\mathrm{NIR})
$$

Where NIR is spectral reflectance in near infrared band and G is spectral reflectance in Green band. In Google Earth Engine platform all the datasets are imported as image collection (predefined function in GEE) with the condition of cloud cover of less than $10 \%$. After importing NDWI operation is done for every scene and area of water pixels are computed using functions in GEE.

\subsection{Estimation of Reservoir Capacity:}

The reservoir capacity is calculated at different levels. Modified trapezoidal formula is used to calculate the volume between different reservoirs (Jayapragasam et al., 1980, Manavalan et al., 1990, Goel and Jain 1996).

$$
\mathrm{V}=\mathrm{h} / 3\left(\mathrm{~A}_{1}+\mathrm{A}_{2}+\operatorname{sqrt}\left(\mathrm{A}_{1} * \mathrm{~A}_{2}\right)\right)
$$

Where ' $h$ ' is height between two consecutive water levels, and ' $\mathrm{A}_{1}$ ' and ' $\mathrm{A}_{2}$ ' are the water spread areas at successive water levels. For estimation of capacity, cumulative reservoir capacity is calculated by adding the volume between different reservoir levels.

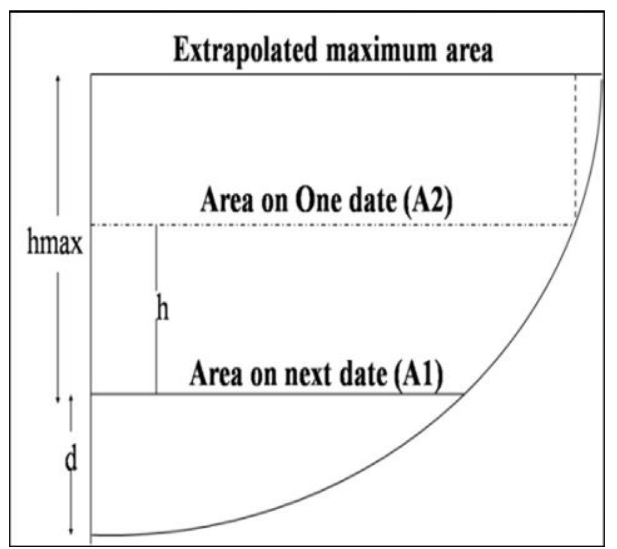

Fig. 2. Modified Trapezoidal Method Line diagram (source: (Shukla et al., 2017)

\subsection{Methodology flowchart:}

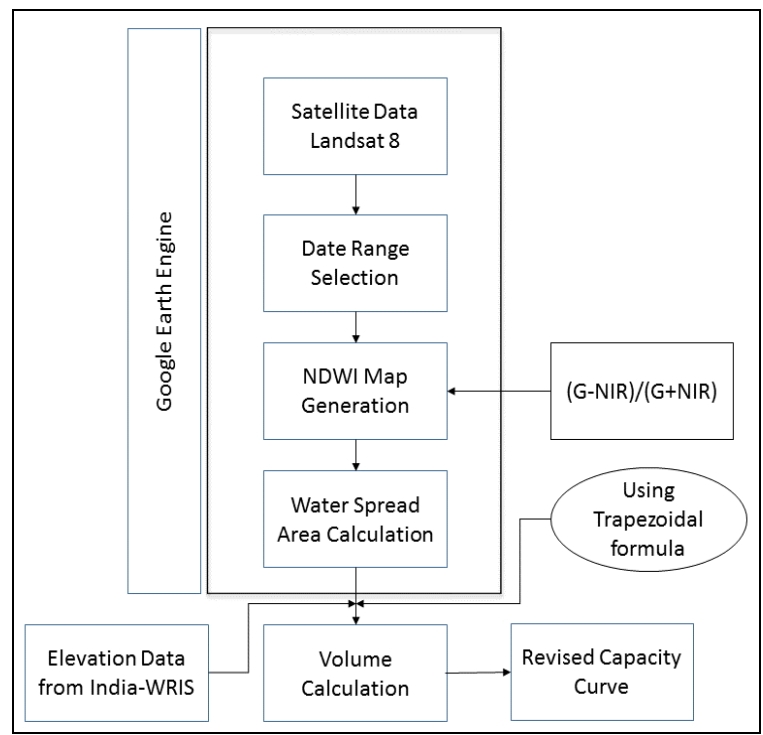

Fig. 3. Methodology flowchart

\section{RESULTS AND DISCUSSIONS}

In this paper the water spread area of the Gobind Sagar reservoir was calculated with the help of GEE. By using NDWI and image stretching methods, the water pixels were differentiated from other land cover land use classes as shown in Fig. 4.1 to 4.4. Trapezoidal formula was used to calculate the difference in volume between two consecutive reservoir levels and is given in Table 3. In this study, the cumulative revised capacity of the reservoir at lowest observed level $(467.38 \mathrm{~m})$ was assumed to be same as the original cumulative capacity (1759.86) obtained from India-WRIS. The cumulative capacities above the lowest observed level, were added up to the estimate the cumulative original and revised capacities at maximum observed level. 

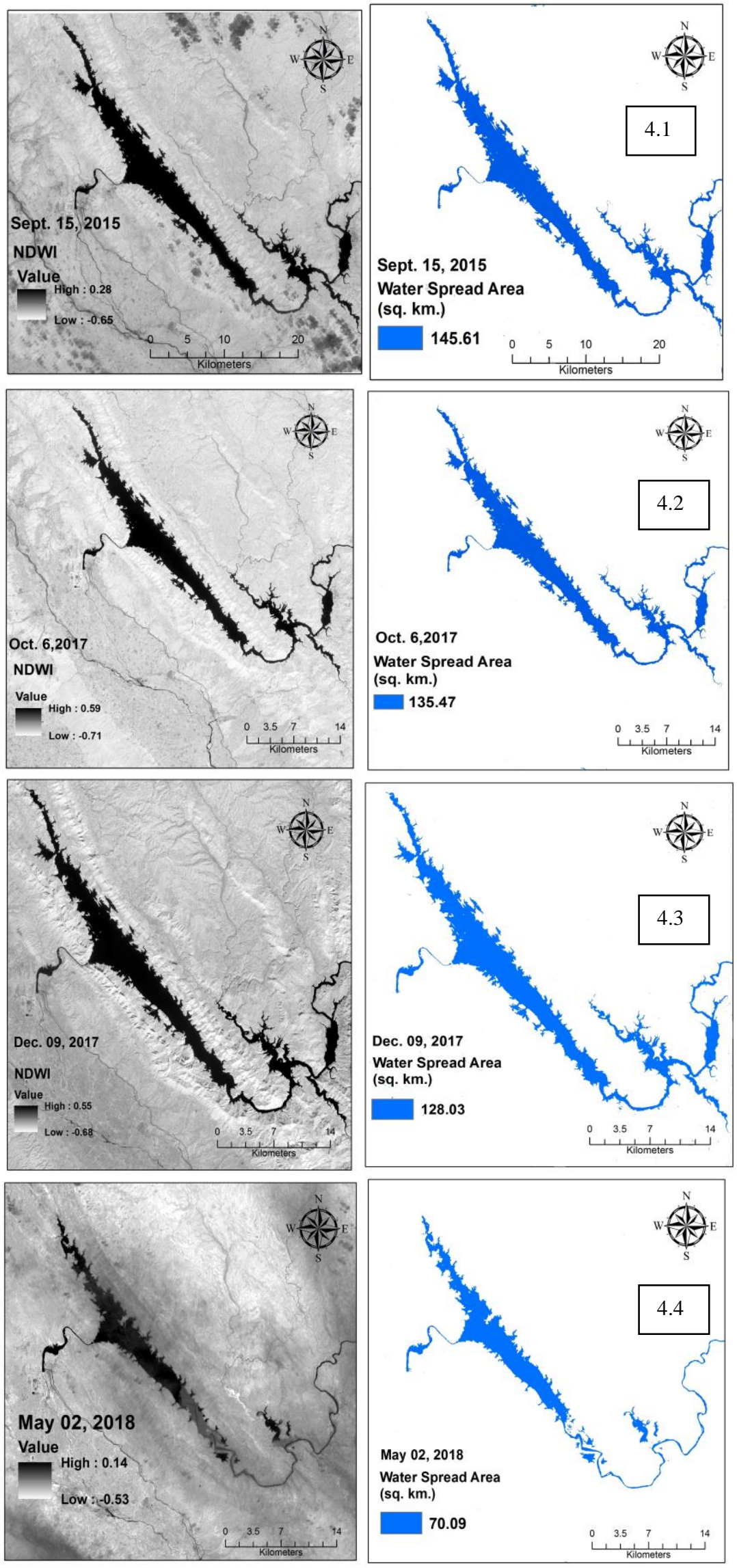

Fig. 4.1 to 4.4 NDWI map of different dates obtained from Google Earth Engine and corresponding masked water pixel. 




Fig. 5 Elevation-Area curves for Gobind Sagar Reservoir, India (2017-2018)

Fig 6 Elevation-Capacity curves for Gobind Sagar Reservoir, India (2017-2018)

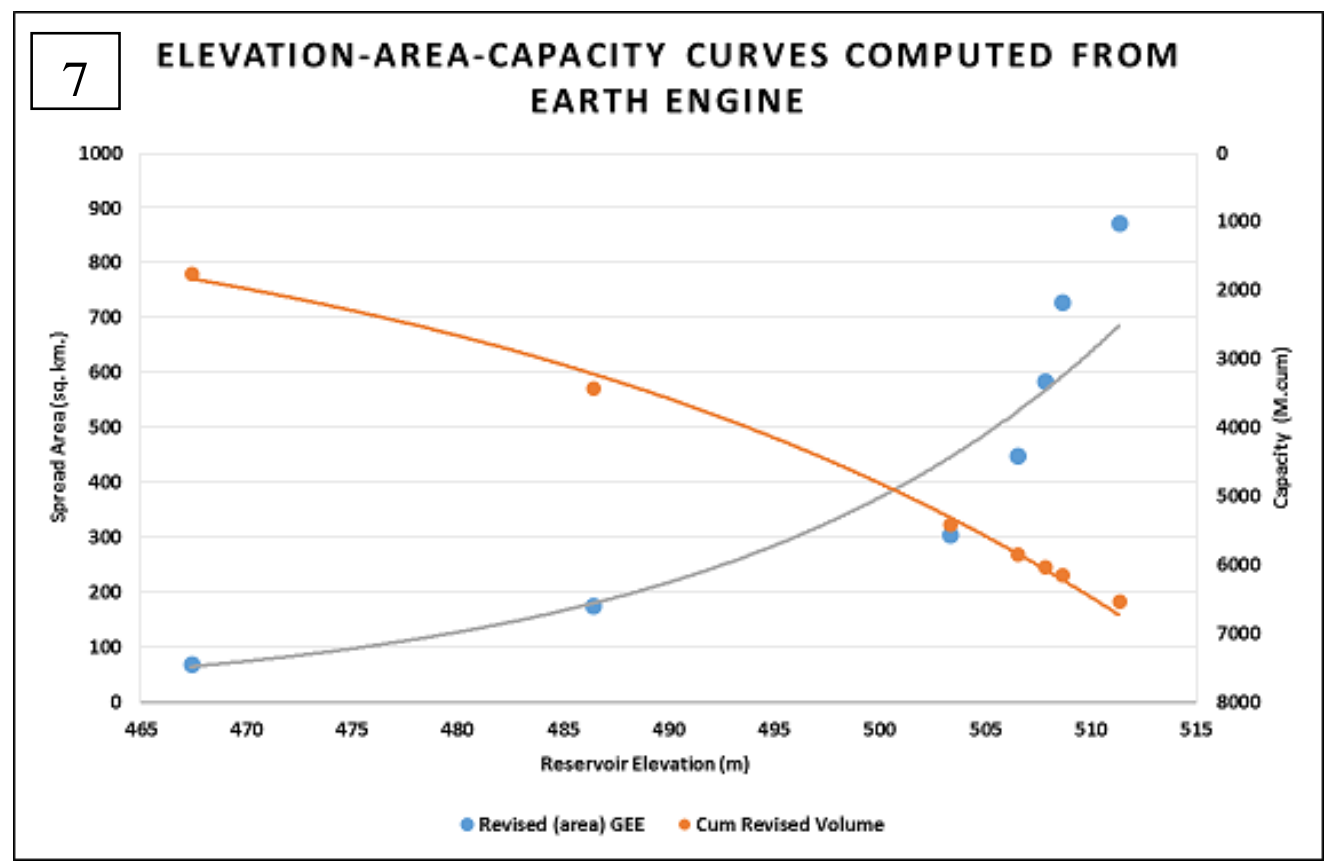

Fig 7 Elevation-Area-Capacity curves for Gobind Sagar Reservoir, India (2017-2018)

Table 3. Assessment of sediments deposition of Gobind Sagar reservoir using remote sensing (GEE) for the year 2017/18

\begin{tabular}{|c|c|c|c|c|c|c|c|}
\hline $\begin{array}{c}\text { Date of } \\
\text { Satellite } \\
\text { pass }\end{array}$ & $\begin{array}{c}\text { Reservoir } \\
\text { level (m) }\end{array}$ & $\begin{array}{c}\text { Original } \\
\text { Area* } \\
\text { (sq. km.) }\end{array}$ & $\begin{array}{c}\text { Estimated } \\
\text { Area } \\
\text { (sq. km.) } \\
\text { (GEE) }\end{array}$ & $\begin{array}{c}\text { Original } \\
\text { Volume* } \\
\text { (M. cum) }\end{array}$ & $\begin{array}{c}\text { Estimated } \\
\text { Volume } \\
\text { (M.cum.) } \\
\text { (GEE) }\end{array}$ & $\begin{array}{c}\text { Original } \\
\text { Cumulative } \\
\text { Volume } \\
\text { (M. cum.) }\end{array}$ & $\begin{array}{c}\text { Estimated } \\
\text { Cumulative } \\
\text { Volume } \\
\text { (M.cum.) }\end{array}$ \\
\hline 2-May-18 & 467.38 & 89.93 & 70.09 & & & 1759.86 & 1759.86 \\
\hline 27-Feb-18 & 486.39 & 119.32 & 106.60 & 1982.35 & 1667.35 & 3742.22 & 3427.21 \\
\hline 9-Dec-17 & 503.31 & 151.69 & 128.03 & 2287.32 & 1982.16 & 6029.54 & 5409.37 \\
\hline 7-Nov-17 & 506.51 & 158.47 & 145.11 & 496.22 & 436.74 & 6525.76 & 5846.11 \\
\hline 6-Oct-17 & 507.8 & 161.26 & 135.47 & 206.22 & 180.94 & 6731.98 & 6027.05 \\
\hline 20-Sep-17 & 508.64 & 163.10 & 142.53 & 136.23 & 116.74 & 6868.21 & 6143.79 \\
\hline 15-Sep-15 & 511.32 & 169.05 & 145.61 & 445.05 & 386.09 & 7313.26 & 6529.88 \\
\hline
\end{tabular}

*Modified from (Sanjay k. Jain , Singh Pratap, 2002) 
The difference between the original and estimated capacity represented the loss of capacity due to sedimentation in the live zone of the reservoir. The detailed calculation is presented in Table 3. The difference between original capacity (7313.26 $\mathrm{Mm}^{3)}$ and capacity estimated for the year 2017/18 using GEE $\left(6529.88 \mathrm{Mm}^{3}\right)$ comes out to be $783.38 \mathrm{Mm}^{3}$ which depicts the loss in capacity due to sedimentation in the zone of study, i.e. between $511.32 \mathrm{~m}$ and $467.38 \mathrm{~m}$ of the reservoir. Thus, the average rate of loss of capacity estimated to be $14.24 \mathrm{Mm}^{3}$ per year for the live zone. The comparison between elevation vs cumulative original and estimated area and elevation vs capacity from GEE for the year 2017/18 is shown in Fig. 5 and Fig. 6 respectively. Further, an Elevation-Area-Capacity curves are prepared as represented in Fig. 7.

\section{CONCLUSION}

Remotely sensed data was conveniently used for assessment of reservoir capacity together with the help of Google Earth Engine. This technique enables quick and accurate live storage capacity estimation loss due to sedimentation. The Gobind Sagar reservoir was first impounded in the year 1963 and the result from analysis of remote sensing approach shows that $783.38 \mathrm{Mm}^{3}$ of Live storage have been lost in last 55 years (1963-2018). The mean sedimentation rate of Gobind Sagar reservoir comes out to be $14.24 \mathrm{Mm}^{3} /$ year and capacity reduction of the reservoir is estimated to be $10.71 \%$. Thus there is a need to arrest the enhanced erosion from the catchment of Gobind Sagar reservoir.

Also, by using remote sensing, capacities only in the live zone of reservoir could be estimated. For the dead load zone, the information on the capacity could be only be taken from the hydrological survey.

\section{REFERENCES}

Durbude, D. G., \& Purandara, B. K. (2005). Assessment of sedimentation in the Linganmakki reservoir using remote sensing. Journal of the Indian Society of Remote Sensing, 33(4), 503-509. https://doi.org/10.1007/BF02990735

Fan, B. J., \& Morris, G. L. (1992). RESERVOIR SEDIMENTATION. I: DELTA AND DENSITY CURRENT DEPOSITS, 118(3), 354-369.

Foteh, R., Garg, V., Nikam, B. R., Khadatare, M. Y., Aggarwal, S. P., \& Kumar, A. S. (2018). Reservoir Sedimentation Assessment Through Remote Sensing and Hydrological Modelling. Journal of the Indian Society of Remote Sensing, 6. https://doi.org/10.1007/s12524-018-0843-6

Garg, V., \& Jothiprakash, V. (2008). Estimation of useful life of a reservoir using sediment trap efficiency. Journal of Spatial Hydrology, $8(2), \quad 1-14$. https://doi.org/10.1017/CBO9780511806049

Goel, M. K., Jain, S. K., \& Agarwal, P. K. (2002). Assessment of sediment deposition rate in Bargi Reservoir using digital image processing. Hydrological Sciences Journal, 47(sup1), S81-S92. https://doi.org/10.1080/02626660209493024

Gorelick, N., Hancher, M., Dixon, M., Ilyushchenko, S., Thau, D., \& Moore, R. (2017). Google Earth Engine: Planetary-scale geospatial analysis for everyone. Remote Sensing of
Environment. https://doi.org/10.1016/j.rse.2017.06.031

Jain, S. K. (2002). Determination of Reservoir Storage Capacity, 1-10. Retrieved from http://nihroorkee.gov.in/NHP/traning_Modules/Reservoir Sizing.pdf

McFeeters, S. K. (1996). The use of the Normalized Difference Water Index (NDWI) in the delineation of open water features. International Journal of Remote Sensing, 17(7), 1425-1432. https://doi.org/10.1080/01431169608948714

Morris, J. T. (1995). The Mass Balance of Salt and Water in Intertidal Sediments: Results from North Inlet, South Carolina. Estuaries, 18(4), 556. https://doi.org/10.2307/1352376

Narayana, D. V. V., \& Babu, R. (1983). Estimation of Soil Erosion in India. Journal of Irrigation and Drainage Engineering, 109(4), 419-434. https://doi.org/10.1061/(ASCE)0733-9437(1983)109:4(419)

Ninija Merina, R. Sashi Kumar, M. C., Rizvana, N., Adlin, R. (2016). Sedimentation Study in a Reservoir Using Remote, 14(4), 296-304.

Sanjay k. Jain , Singh Pratap, S. S. M. (2002). Assessment of sedimentation in Bhakra Reservoir in the western Himalayan region using remotely sensed data. Hydrological Sciences Journal, 47(2), 37-41.

Shalash, S. (1982). Effects of sedimentation on the storage capacity of the High Aswan Dam reservoir. Hydrobiologia, 9192(0), 623-639. https://doi.org/10.1007/BF00000061

Shrestha, B., Babel, M. S., Maskey, S., van Griensven, A., Uhlenbrook, S., Green, A., \& Akkharath, I. (2012). Impact of climate change on sediment yield in the Mekong River Basin: a case study of the Nam Ou Basin, Lao PDR. Hydrology and Earth System Sciences Discussions, 9(3), 3339-3384. https://doi.org/10.5194/hessd-9-3339-2012

Shukla, S., Jain, S. K., Kansal, M. L., \& Chandniha, S. K. (2017). Assessment of sedimentation in Pong and Bhakra reservoirs in Himachal Pradesh, India, using geospatial technique. Remote Sensing Applications: Society and Environment, 8(August), $148-156$. https://doi.org/10.1016/j.rsase.2017.08.008

Singh, P., \& Kumar, N. (1997). Effect of orography on precipitation in the western Himalayan region. Journal of Hydrology, 199(1-2), 183-206. https://doi.org/10.1016/S00221694(96)03222-2

Verpoorter, C., Kutser, T., Seekell, D. A., \& Tranvik, L. J. (2014). A global inventory of lakes based on high-resolution satellite imagery. Geophysical Research Letters, 41(18), 63966402. https://doi.org/10.1002/2014GL060641

Xiong, J., Thenkabail, P. S., Gumma, M. K., Teluguntla, P., Poehnelt, J., Congalton, R. G., ... Thau, D. (2017). Automated cropland mapping of continental Africa using Google Earth Engine cloud computing. ISPRS Journal of Photogrammetry and Remote Sensing, 126, 225-244. https://doi.org/10.1016/j.isprsjprs.2017.01.019 
The International Archives of the Photogrammetry, Remote Sensing and Spatial Information Sciences, Volume XLII-5, 2018 ISPRS TC V Mid-term Symposium "Geospatial Technology - Pixel to People”, 20-23 November 2018, Dehradun, India

Zeltner, N. (2016). Using the Google Earth Engine for Global Glacier Change Assessment, (October), 93. 